\title{
The Origins of the Liberal Welfare Reforms 1906-1914
}




\section{STUDIES IN ECONOMIC AND SOCIAL HISTORY}

This series, specially commissioned by the Economic History Society, provides a guide to the current interpretations of the key themes of economic and social history in which advances have recently been made or in which there has been significant debate.

Originally launched in 1968 as 'Studies in Economic History', in 1974 the series had its scope extended to include topics in social history, and the new series title 'Studies in Economic and Social History' marked this development. This series was completed in 1995. A new series, published by Cambridge University Press and entitled 'New Studies in Economic and Social History', has now been inaugurated and this includes a number of reissued titles previously published by Macmillan.

Titles still available from Macmillan are given below, followed by a listing of those titles now available from Cambridge University Press.

\section{STUDIES IN ECONOMIC AND SOCIAL HISTORY} (published by Macmillan)

B. W. E. Alford Depression and Recovery? British Economic Growth, 1918-1939

M. Anderson Population Change in North-Western Europe, 1750-1850

S. D. Chapman The Cotton Industry in the Industrial Revolution, 2nd edition

M. E. Falkus The Industrialisation of Russia, 1700-1914

J. R. Harris The British Iron Industry, 1700-1850

J. Hatcher Plague, Population and the English Economy, 1348-1530

J. R. Hay The Origins of the Liberal Welfare Reforms, 1906-1914

H. McLeod Religion and the Working Classes in Nineteenth-Century Britain

J. D. Marshall The Old Poor Law, 1795-1834, 2nd edition

R. J. Morris Class and Class Consciousness in the Industrial Revolution, 1750-1850

P . K. O'Brien The Economic Effects of the American Civil War

P. L. Payne British Entrepreneurship in the Nineteenth Century

G. C. Peden Keynes, the Treasury and British Economy Policy

M. E. Rose The Relief of Poverty, 1834-1914

S. B. Paul The Myth of the Great Depression, 1873-1896, 2nd edition

J. Thirsk England's Agricultural Regions and Agrarian History $1500-1750$

J. R. Ward Poverty and Progress in the Caribbean, 1800-1960 


\title{
The Origins of the Liberal Welfare Reforms 1906-1914
}

\author{
Prepared for \\ The Economic History Society by \\ J. R. HAY
}

palgrave 


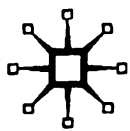

( The Economic History Society 1975, 1983

All rights reserved. No reproduction, copy or transmission of this publication may be made without written permission.

No paragraph of this publication may be reproduced, copied or transmitted save with written permission or in accordance with the provisions of the Copyright, Designs and Patents Act 1988, or under the terms of any licence permitting limited copying issued by the Copyright Licensing Agency, 90 Tottenham Court Road, London W1T 4LP.

Any person who does any unauthorised act in relation to this publication may be liable to criminal prosecution and civil claims for damages.

The authors have asserted their rights to be identified as the authors of this work in accordance with the Copyright, Designs and Patents Act 1988.

First edition 1975

Reprinted 1977, 1980, 1982

Revised edition 1983

Reprinted 1986, 1987

Published by

PALGRAVE

Houndmills, Basingstoke, Hampshire RG21 6XS and

175 Fifth Avenue, New York, N. Y. 10010

Companies and representatives throughout the world

PALGRAVE is the new global academic imprint of

St. Martin's Press LLC Scholarly and Reference Division and Palgrave Publishers Ltd (formerly Macmillan Press Ltd).

ISBN 978-0-333-36000-2 ISBN 978-1-349-06941-5 (eBook)

DOI 10.1007/978-1-349-06941-5

This book is printed on paper suitable for recycling and made from fully managed and sustained forest sources.

A catalogue record for this book is available from the British Library.

$\begin{array}{llllll}12 & 11 & 10 & 9 & 8 & 7\end{array}$

$\begin{array}{llllll}06 & 05 & 04 & 03 & 02 & 01\end{array}$ 
Contents

Acknowledgements $\quad 7$

Note on References 7

Editor's Preface 9

1 Introduction 11

2 Approaches to the Reforms 15

(i) Social scientists and the introduction of social welfare legislation $\quad 15$

(ii) Historians and the Liberal Reforms 19

3 The Roots of the Reforms 25

(i) Pressure from below 25

(ii) Changing attitudes to welfare provision 29

(iii) Institutional influences 38

4 The Process of Reform 43

(i) Children and the old 43

(ii) Unemployment and minimum wages 47

(iii) Health insurance 54

(iv) Fiscal policy 57

5 Conclusion 61

References $\quad 65$

Bibliography $\quad 67$

$\begin{array}{ll}\text { Index } & 75\end{array}$ 


\section{Acknowledgements}

I wish to thank my colleagues in the Departments of Economic History at the Universities of East Anglia and Glasgow and Dr M. E. Rose of the University of Manchester for their comments on various drafts of this book. My debt to the General Editor of this series, for his assistance which went far beyond the duties laid on him, cannot be adequately expressed here.

Notes on References

References in the text within square brackets relate to the Bibliography, followed by the date of publication and, where appropriate, by the page number in italics, e.g. [Briggs, 1961b, 222]. Other references in the text, numbered consecutively, relate to sources itemised in the References section. 


\section{Editor's Preface}

SO long as the study of economic and social history was confined to a small group at a few universities, its literature was not prolific and its few specialists had no great problem in keeping abreast of the work of their colleagues. Even in the 1930s there were only two journals devoted exclusively to economic history and none at all to social history. But the high quality of the work of the economic historians during the inter-war period and the post-war growth in the study of the social sciences sparked off an immense expansion in the study of economic history after the Second World War. There was a great expansion of research and many new journals were launched, some specialising in branches of the subject like transport, business or agricultural history. Most significantly, economic history began to be studied as an aspect of history in its own right in schools. As a consequence, the examining boards began to offer papers in economic history in all levels, while textbooks specifically designed for the school market began to be published. As a specialised discipline, social history is an even more recent arrival in the academic curriculum. Like economic history, it, too, is rapidly generating a range of specialist publications. The importance of much of the recent work in this field and its close relationship with economic history have therefore prompted the Economic History Society to extend the scope of this series - formerly confined to economic history to embrace themes in social history.

For those engaged in research and writing this period of rapid expansion of studies has been an exciting, if rather breathless one. For the larger numbers, however, labouring in the outfield of the schools and colleges of further education, the excitement of the explosion of research has been tempered by frustration arising from its vast quantity and, frequently, its controversial character. Nor, it must be admitted, has the ability or willingness 
of the academic historians to generalise and summarise marched in step with their enthusiasm for research.

The greatest problems of interpretation and generalisation have tended to gather round a handful of principal themes in economic and social history. It is, indeed, a tribute to the sound sense of economic and social historians that they have continued to dedicate their energies, however inconclusively, to the solution of these key problems. The results of this activity, however, much of it stored away in a wide range of academic journals, have tended to remain inaccessible to many of those currently interested in the subject. Recognising the need for guidance through the burgeoning and confusing literature that has grown around these basic topics, the Economic History Society hopes in this series of short books to offer some help to students and teachers. The books are intended to serve as guides to current interpretations in major fields of economic and social history in which important advances have recently been made, or in which there has recently been some significant debate. Each book aims to survey recent work, to indicate the full scope of the particular problem as it has been opened up by recent scholarship, and to draw such conclusions as seem warranted, given the present state of knowledge and understanding. The authors will often be at pains to point out where, in their view, because of a lack of information or inadequate research, they believe it is premature to attempt to draw firm conclusions. While authors will not hesitate to review recent and older work critically, the books are not intended to serve as vehicles for their own specialist views: the aim is to provide a balanced summary rather than an exposition of the author's own viewpoint. Each book will include a descriptive bibliography.

In this way the series aims to give all those interested in economic and social history at a serious level access to recent scholarship in some major fields. Above all, the aim is to help the reader to draw his own conclusions, and to guide him in the selection of further reading as a means to this end, rather than to present him with a set of pre-packaged conclusions.

University of Edinburgh

M. W. FLINN AND T. C. SMOUT 